\title{
DOS CUENTOS
}

Jonathan Jesús García Palma*

\section{Intervención}

Graciela le informó de sus planes de suicidio la mañana del treinta de marzo. Se lo dijo afuera del salón de clases, con los ojos enrojecidos. No había lágrimas, pero su corazón era un mar. Se contenía. Pretendía soportar. La resolución estaba tomada. De antemano, su muerte estaba asegurada por algo que ella denominaba destino. Convencida de la invariabilidad de su final, se dejaba llevar por lo escrito, lo acordado, lo concatenado por una entidad superior a la cual prefería concebir carente de cuerpo, únicamente como energía, poder. De acuerdo con su pensar, esa esencia actuaba, pensaba, dictaba y juzgaba. Ella se asumía sentenciada.

La joven mujer se rendía ante un veredicto considerado injusto y cruel. Deseaba continuar luchando; sin embargo, sus energías escaseaban. Guardaría su último aliento para elegir, por lo menos, la forma en que permitiría la consumación del doloroso pasaje. Esa sería su última carta, la jugada final, el movimiento definitivo. Reflejo de su lucha, bandera de su enardecida confrontación, dicha decisión, al transformarse en acto, se constituiría como la victoria de una batalla en medio de una guerra perdida. "Dormiré, simplemente dormiré", le dijo a su confidente.

* Escritor y pedagogo. 
El suicidio nunca se había aproximado tanto a él. Así, la muerte, constantemente cercana a su existencia, le tomaba la mano y lo obligaba a verla directamente a los ojos. Esa mirada, profunda y superficial, distante e inmediata, vacía y al mismo tiempo rebosante de sentido, se fijó en sus pupilas y llegó al centro de su alma. Ahí estaba la muerte, afirmándose, reiterando su poder, desafiándolo. Graciela era tan solo una mujer más, una persona a punto de cruzar la línea. Él era el testigo, el silencioso e insignificante sujeto capaz de intervenir en el curso de una historia previamente diseñada. Graciela, sin saberlo, lo retaba a él. Retaba a esa finitud deseosa de hallar la infinitud lo más tarde posible.

La pregunta no era qué se podía hacer. El verdadero cuestionamiento era si él estaría dispuesto a actuar. De una forma u otra podía evitar la muerte de Graciela; pero, ¿a qué precio? ¿Realmente interferiría con su libertad para tranquilizar su conciencia? ¿Quién importaba en realidad? Graciela era ella; él era él. ¿Acaso la joven pretendía, con aquellas palabras, solicitar su ayuda? Su boca, sus ojos, todo su ser afirmaba lo contrario. Simplemente se despedía. Sin embargo, él dudaba. Con base en esa duda, partiendo de ese dilema, convertido en un ser egoísta, decidió aplazar la partida. Ella se dejó arrastrar. "Está bien. He perdido", dijo mientras él la ataba de pies y manos para, posteriormente, subirla al automóvil.

Han transcurrido muchas semanas desde aquel día. Él no ha dejado de pensar en ella ni un solo momento. Ve su mirada a cada instante, al abrir y cerrar los ojos. Ahí está Graciela. No obstante, a pesar de observarla de frente, sabe que ella, donde quiera que esté, le da la espalda. Se voltea, resignada y molesta al mismo tiempo. Probablemente culpa al destino, pero lo maldice a él, reprochándole su soberbia, su arrogante intervención. Ella pretendía dormir a su modo y él la sumergió en un sueño precedido de un intenso dolor. Ciertamente, esa nunca fue la intención de él. La autopista lo sabe. El destino lo sabe. La muerte, también.

Precisamente por eso, él no falleció a consecuencia del accidente. Empero, ahora, ni siquiera puede morir cuando lo desee. Inmóvil, distante y cercano al mismo tiempo, se encuentra en medio del mundo, pero 
ajeno a él. Serán las existencias circundantes quienes, imitándolo, decidan el camino a seguir. Lo harán por él, con él, tal vez sin él. Mientras tanto, está condenado a vivir únicamente dentro de sí.

\section{Camino a casa}

Mabel giró la cabeza y miró, por encima del hombro y sin detenerse, a quien fuera su esposo. Aquel hombre le pareció pequeño, diminuto. Lo consideró insignificante. Sin embargo, había sido su compañero de vida durante los últimos veinte años y, a pesar de todo, aún le guardaba un cariño especial. Ya nada los uniría después de ese día. Por esa razón continuó caminando, aunque sus ojos miraban hacia atrás y no hacia el frente. Su mente y su corazón se orientaban al pasado, no al futuro. Andaba con paso firme, pero inseguro. Se despedía de una parte de sí y comenzaba un presente distinto, desconocido.

Llegó a su automóvil, estacionado a unos cuantos metros de la estación de tren. Quiso volver a donde se hallaba él. Sabía que ahí continuaría quien le prometiera amor eterno frente a un altar. Quieto, en silencio: ahí estaría. Después de recordar la magnífica boda y los buenos momentos vividos, antes y después de la unión, abrió la puerta del coche. Se detuvo. Por segunda ocasión sintió la necesidad de regresar. Se contuvo. Luchó contra su corazón. Sollozó. Instantes más tarde sus ojos se convirtieron en un manantial.

Había finalizado la historia de amor y convivencia, pero ella continuaba confundida. Desconocía cuanto sucedería después. Aquel día se constituía como un hito en su existencia, y en la de él. Nada volvería a ser igual. Al meditar en ello, recordó que no serían los únicos afectados por lo ocurrido. "Será por última vez", pensó después de resolver efectuar una despedida adecuada. Cerró la puerta del vehículo y emprendió el camino de regreso.

Faltaban unos cuantos metros para llegar al sitio en donde seguía él, en la estación de tren. Mabel caminaba lentamente. De pronto, una mujer pasó corriendo a su lado. La reconoció al instante: era ella, el nuevo amor de quien fuera su esposo. Era ella. Mabel se detuvo. Comprendiendo lo 
inútil de su presencia en el sitio, reinició el camino a casa. Todo había terminado; no hacía falta otro adiós. Era el final.

Segundos más tarde se escuchó un fuerte grito. Una voz femenina pedía ayuda desesperadamente. Mabel giró la cabeza y miró, por encima del hombro y sin detenerse, a quien fuera su esposo. Aquel hombre le pareció delgado, demacrado. Lo consideró insignificante. Sin embargo, había sido su compañero de vida durante los últimos veinte años $\mathrm{y}$, a pesar de todo, aún le guardaba un cariño especial. Por tal motivo lo había herido en el corazón. No quiso verlo sufrir mucho tiempo.

Dejando atrás el desorden ocasionado por la tragedia, Mabel continuó con paso firme, pero inseguro. Se despedía de una parte de sí y comenzaba un presente distinto, desconocido, sin amor. Le complacía saber que no sería la única que dormiría sin el ser amado a su lado. Al llegar al automóvil guardó el cuchillo, aún lleno de sangre, dentro del bolsillo de su abrigo y abrió la puerta. Iniciaba el camino de regreso a casa. 